\title{
PSYCHOLOGY
}

\section{The personality features of the professional and amateur musicians}

\author{
I. F. Arshava, V. U. Kutepova-Bredun
}

The O.Honchar Dnipro National University

Paper received 08.12.17; Revised 12.12.17; Accepted for publication 18.12.17. https://doi.org/10.31174/SEND-PP2018-153VI63-15

Abstract. The article proved that the personality features of the professional and amateur musicians have the statistically significant differences. The professional musicians as a group have the high level of creativity together with the high levels of neuroticism, anxiety, asthenic states. The amateur musicians as a group have the emotional stability, the high levels of moral normativity with the positive attitude towards the musical activity. The hypothesis is proved as to the choice of creative activity as a profession is connected with the need of the self-realization of the creative person, the expression of the anxiety, flow states by means of musical activity. As for the amateurs, the musical activity is probably a form of entertainment for them that is proved by the differences in personal features.

Keywords: professional musicians, amateurs, neuroticism, emotional stability, moral normativity, psychological well-being.

Introduction. The presence of specific musical abilities determines the choice of musical activity as a profession but apart from musical abilities strong motivation is necessary for a decision to choose musical activity as a permanent type of activity [12]. Authors have formulated the hypotheses that particular psychological features predetermine the choice of musical activity as profession. Firstly, musical activity creates the possibility to express their emotional states for talented professionals, both positive and negative and, secondly, gives possibility of experiencing a unique mental state of "flow" that arises up at the terms of achievement a high level of skillful perfection and gives possibility to feel the high level of pleasure. For the hypothesis verification we chose an approach that was based on the comparison of personality peculiarities among professional musicians and amateur musicians.

Literature review. More than three decades researchers tried to define those features that distinguish musicians from the representatives of other professions (Bell \&Creswell, 1984; Cutietta \& McAllister, 1997; Davies, 1975; Kemp.)[4,10]

K.I.Kurbatova defined the complex of characteristics of the musically gifted teenagers that distinguish them from teenagers with average abilities. That are: higher level of intellect, certain emotional features and motiveco-coordinating skills. Also the gifted teenagers are capable to structure the material and to think logically. They are also characterized by higher emotional sensitivity $[8,16]$.

American psychologist A. Kemp (1996, 2000) conducted one of the biggest researches of musicians personality. His data testifies that, young musicians as a group, meaningfully differ from non-musicians in the level of introversion with the elements of estrangement among the most talented musicians[11].

On the basis of these data A.Kemp marks that musicians as a group are introverts and, together with it, differ in "bravery" that is formed not only with considerable internal resources, but also with the high level of their independence. The level of the last feature grows with an increase to the level of musical experience [10]. The group of more mature musicians-professionals in comparison with non- musicians has a meaningful higher levels of sensitivity, imagination and intuition (that Cattel defines as Pathemia). This property of musicians is related to their sentimentality, and emotional perception of reality[11].

If the problem of research of specific personality features of the professional musicians interested both home and foreign researchers, the personality features of amateur musician are studied less. Some foreign researchers mark positive influence of active music fascination on the physical and psychological health of people (Bailey \& Davidson, 2005; Coffin, 2005; Coffman \& Adamek, 1999; Hartley, 2003 Rohwer, 2002, 2009, 2010; Shansky, 2010)[3]. The results of researches of personality of amateur musicians usually concern their high level of social co-operation and sense of well-being [4].

Professionals that work with amateurs mention their high level of motivation, pleasure that they feel from music performance and social co-operating with other participants of musical groups (Cavitt, 2005; Coffman \& Levy, 1997; Cope, 2005; Palmer 2008, Rohwer, 2002)[6] .Don Coffman wanted to check the hypothesis that the personal features of the professional and amateur musicians will be the same but they will verify only in intensity of the certain features but the results were unexpected. The amateurs display traits in the opposite direction from professional musicians. Using the 16 PF Coffman described the amateur personality of amateur musician as a "normal" personality that tends to the middle $68 \%$ of the $16 \mathrm{PF}$ standard score ranges. But the more detailed research shows that the amateur are more accommodating (IN-), deferential (E-), serious (F-), trusting (L-), and thinking more abstractly $(\mathrm{B}+)$. It's important to notice that Coffman held his research on the old amateur musicians. The researcher notices that because of the age they tend to be less adaptive and flexible than young amateur musicians [5].

The research of the amateur personality by the method of self-report was held by D.Chiodo (1997) and P.Griffit (2006). It showed that $50 \%$ of amateur musicians characterize their personality as artistic, intellectual and energetic. Less than half respondents characterize themselves as brave, positive and imaginative. L.Duglas (2011) marks competence and autonomy as amateur personal features. [14].

T.L Kuntz (2012) by the self-report method (300 adjectives «Adjective list») defined 10 personal features of amateur musicians. Amateurs characterize themselves as 
Dependable $(80.9 \%, \mathrm{n}=182)$, Active $(80 \%, \mathrm{n}=180)$, Honest $(78.7 \%, \mathrm{n}=177)$, a $(75.6 \%, \mathrm{n}=170)$, Capable $(74.7 \%, \mathrm{n}=168)$, Friendly $(71.1 \%, \mathrm{n}=160)$, Conscientious $(70.2 \%, \mathrm{n}=158)$, Adaptable $(69.8 \%, \mathrm{n}=157)$, Appreciative $(69.8 \%, \mathrm{n}=157)$ тa Practical $(69.3 \%, \mathrm{n}=156)$. This research was also conducted on the amateurs above 50 years old[14].

The results of the above analyzed contemporary researches of comparison the personal characteristics of the professional and amateur musicians show the lack of empirical data comprehending the personality of young amateur musicians and the necessity of using more variable psychodignotical methods for studying the personal features of involvement to musical culture.

Aim. The purpose of the article is to check the hypothesis related to the differences in the personal characteristics of the professional and amateur musicians. Particularly that the professional musicians have the deeper internal need for the realization of their anxiety, emotional sensitivity introversion, on one hand, and the evidence of the positive experience of the "flow" state on the base of the high level of musical performance than increase the personal psychological well-being.

The materials and methods. The sample of participants included 122 musicians, involved into the empirical research included participants, aged 18-60 years (83 female, 39 - male). The group of professional musicians
( $n=62$ ) was represented by students of M.Glinka Dnipro Concervatoire and the orchestra musicians of T.Shevchenko Drama Theatre. The comparison group ( $n=60$ of amateur musicians, was represented by the students of Oles Honchar Dnipro National University and their adult friends and relatives for whom music is a hobby. Participants were not paid for their services but they had an opportunity to get an individual feedback of the results of the personal psychological data.

Dispositional traits were assessed with five psychodiagnostic methods: the Scales of Psychological Well-Being (Ryff, 1989, adapted by T.Shevelenkova and T.Fesenko), NEO Five-Factor Inventory (Costa et al., 1992, adapted by V.Orel), Multi-Factory Personal Questionnaire Adaptivity » (A. Maklakov, C.Chermyanin) and the Hospital Anxiety and Depression Scales HADS (A.S. Zigmond, R.P. Snaith, 1983, adapted by M. Drobizgev)and the Personal creativity inventory (O.Tunik). The comparative analysis of personal traits of professional and amateur musicians was performed in the course of a quasiexperimental empirical research with two non-equivalent groups of participants (professional and amateurs), the differences in the personality traits of which were assessed with the help of Mann-Whitney U-test.

The results and discussion. The comparison of dispositional personal characteristics of the groups showed the differences only in the level of neuroticism (table 1).

Table 1. Interpersonal differences of professional and amateur musicians in dispositional personal characteristics

\begin{tabular}{|l|c|c|c|c|}
\hline \multicolumn{1}{|c|}{ Scales } & $\begin{array}{c}\text { Professional } \\
\text { musicians }\end{array}$ & $\begin{array}{c}\text { Amateur } \\
\text { musicians }\end{array}$ & U emp & $\begin{array}{c}\text { The level of meaningful } \\
\text { differences }\end{array}$ \\
\hline Extraversion & 50,3871 & 53,23729 & 1473 & 0,065 \\
\hline Agreeableness & 52,6129 & 53,11864 & 1772,5 & 0,769 \\
\hline Consciousness & 52,91935 & 50,59322 & 1626 & 0,292 \\
\hline Neuroticism & $\mathbf{5 1 , 9 0 3 2 3}$ & $\mathbf{4 7 , 7 1 1 8 6}$ & $\mathbf{1 4 2 3}$ & $\mathbf{0 , 0 3 5} *$ \\
\hline Openness to new experience & 58,22581 & 57,67797 & 1822,5 & 0,973 \\
\hline
\end{tabular}

The data shows that professional musicians as a group show higher meanings of the factor "Neuroticism" that show differences in the emotion control[7].

High meanings of neuroticism correspond the data of empirical research of the Hospital Scale of Anxiety and

Depression, that also show the high level of anxiety among professional musicians in comparison with amateur musicians (table 2).

Table 2. Interpersonal differences of professional and amateur musicians in the tendency to anxiety and depression

\begin{tabular}{|l|c|c|c|c|}
\hline \multicolumn{1}{|c|}{ Scales } & $\begin{array}{c}\text { Professional } \\
\text { musicians }\end{array}$ & $\begin{array}{c}\text { Amateur } \\
\text { musicians }\end{array}$ & U emp & $\begin{array}{c}\text { The level of meaningful } \\
\text { differences }\end{array}$ \\
\hline Anxiety & $\mathbf{7 , 1 1 2 9 0 3}$ & $\mathbf{5 , 7 6 2 7 1 2}$ & $\mathbf{1 2 8 8 , 5}$ & $\mathbf{0 , 0 0 5}^{*}$ \\
\hline Depression & 4,33871 & 5,186441 & 1482 & 0,07 \\
\hline \multicolumn{5}{|c|}{${ }^{*} \leq .05$} \\
\hline
\end{tabular}

In the scales of the psychological well-being the statistically meaningful differences were found in the level of both the general scale of psychological well-being and the

scales of "Autonomy" and "Personal growth" in particular that influenced as well on the common level of psychological well-being $[2,15]$ (table 3$)$.

Table 3. Interpersonal differences of professional and amateur musicians in the Scales of psychological well-being

\begin{tabular}{|l|c|c|c|c|}
\hline \multicolumn{1}{|c|}{ Scales } & $\begin{array}{c}\text { Professional } \\
\text { musicians }\end{array}$ & $\begin{array}{c}\text { Amateur } \\
\text { musicians }\end{array}$ & U emp & $\begin{array}{c}\text { The level of meaningful } \\
\text { differences }\end{array}$ \\
\hline Positive relations with others & 59,532 & 61,017 & 1536 & 0,128 \\
\hline Autonomy & $\mathbf{5 9 , 2 9 0}$ & $\mathbf{5 4 , 5 2 5}$ & $\mathbf{1 2 2 7}$ & $\mathbf{0 , 0 0 2} *$ \\
\hline Environmental mastery & 58,306 & 56,576 & 1710 & 0,537 \\
\hline Personal growth & $\mathbf{6 7 , 0 6 5}$ & $\mathbf{6 0 , 3 9 0}$ & $\mathbf{9 7 6}$ & $\mathbf{0 , 0 0 1} * *$ \\
\hline Purpose in life & 67,823 & 62,763 & 1598 & 0,31 \\
\hline Self-acceptance & 56,081 & 52,627 & 1547 & 0,143 \\
\hline $\begin{array}{l}\text { The general index of psycho- } \\
\text { logical well-being }\end{array}$ & 370,097 & 345,898 & $\mathbf{1 0 1 9}$ & $\mathbf{0 , 0 0 1}$ \\
\hline
\end{tabular}


Professional musicians in comparison with amateur musicians are more independent, capable to stand the social pressure in their thoughts and actions and regulate their behavior.

They have a sense of continuity of self-development, self-perfection and a sense of realization of the potential[15]. The mentioned scales influenced on meaningful higher level of general index of psychological well-being of professionals musicians.
Table.4. testifies the presence statistically meaningful differences in a multilevel personality questionnaire "Adaptivity" between the groups of musiciansprofessionals and musicians-amateurs. Statistically meaningful differences were found in the scales of "Moral normativity" and "Asthenic states". Musicians-amateurs in comparison with musicians-professionals have significantly higher level of moral normativity, that in terms of authors of questionnaire testifies the ability to perceive adequately a certain social role.

Table 4. Interpersonal differences of professional and amateur musicians in Adaptive potential

\begin{tabular}{|l|c|c|c|c|}
\hline \multicolumn{1}{|c|}{ Scales } & $\begin{array}{c}\text { Professional } \\
\text { musicians }\end{array}$ & $\begin{array}{c}\text { Amateur } \\
\text { musicians }\end{array}$ & U emp & $\begin{array}{c}\text { The level of meaningful } \\
\text { differeences }\end{array}$ \\
\hline Behaviour regulation & 3,855 & 3,576 & 1532,5 & 0,117 \\
\hline Communicational potential & 4,113 & 4,288 & 1824 & 0,979 \\
\hline Moral normativety & $\mathbf{4 , 4 0 3}$ & $\mathbf{5 , 4 4 1}$ & $\mathbf{1 2 2 0}$ & $\mathbf{0 , 0 0 1} * *$ \\
\hline Asthenic state & $\mathbf{3 , 5 8 1}$ & $\mathbf{4 , 0 5 1}$ & $\mathbf{1 3 8 5}$ & $\mathbf{0 , 0 1 2} *$ \\
\hline Psychotic state & 3,952 & 3,898 & 1728 & 0,582 \\
\hline Desadaptational disorders & 3,952 & 3,746 & 1541,5 & 0,119 \\
\hline
\end{tabular}

The table 5 shows that there are significant differences in the scales of risk level, curiosity and the openness to the new experience

\begin{tabular}{|l|c|c|c|c|}
\hline \multicolumn{1}{|c|}{ Scales } & $\begin{array}{c}\text { Professional } \\
\text { musicians }\end{array}$ & $\begin{array}{c}\text { Amateur } \\
\text { musicians }\end{array}$ & U емп & $\begin{array}{c}\text { The level of meaningful } \\
\text { differences }\end{array}$ \\
\hline Risk level & $\mathbf{1 5 , 6 3 0}$ & $\mathbf{1 2 , 2 6 1}$ & $\mathbf{7 3 7 , 5}$ & $0,007 * *$ \\
\hline Curiosity & $\mathbf{1 4 , 5 0 0}$ & $\mathbf{1 2 , 1 5 2}$ & $\mathbf{7 4 9 , 5}$ & $\mathbf{0 , 0 2 3} * * *$ \\
\hline The difficulty level & 13,326 & 12,891 & 1006 & 0,817 \\
\hline Imagination & 10,891 & 11,087 & 1028 & 0,956 \\
\hline Creativity & $\mathbf{5 4 , 3 4 8}$ & 48,391 & $\mathbf{7 0 9}$ & $\mathbf{0 , 0 1} * *$ \\
\hline
\end{tabular}

Conclusion. The hypothesis of the research has been confirmed - the level of involvement into musical activity influences not only the personality trait characteristics of the participants but also their level of psychological wellbeing and adaptive abilities. The research proved the statistically significant difference in several personal traits of professional and amateur musicians.

Firstly, it was proved that professional and amateur musicians differ in the level of emotional sensitivity, that is evidenced by the statistically significant differences in the scale of neuroticism as a dispositional feature and the high level of anxiety. The characteristic feature of the professional musicians is also the inclination to the as- thenic states. They also can be characterized by the high levels of autonomy, inclination to risk and moral normativity. The research has also confirmed the high level of the creativity of the professional musicians.

The paradox that the professional musicians have the high level of psychological well-being together with such dispositional personality features as anxiety, neuroticism, we explain by their ability to experience the "Flow" state (which is defined in the terms of positive psychology). This state gives them possibility to experience the personal well-being. The perspective of the problem we see in verification of the role of the "flow" state on the wellbeing of the professional musicians.

\section{REFERENCES}

1. Arshava I., Kutepova-Bredun V. (2011). Psihologichni osoblivosti muzikantiv $\mathrm{v}$ konteksti psihologichnogo zdorov'ya [Psychological personal peculiarities of the musician in the context of psychological health]. Medical psychology. Vol.2, 3-7. (in Ukrainian).

2. Arshava I.F., Znanecka O.M., Nosenko E.L. (2011) Pozitivnist' obrazu Ja i psihologichne blagopoluchchja osobistosti [The positivity of self-image and the psychological well-being of the personality], Dnipropetrovsk 'Innovation' Press, 38-64. (in Ukrainian).

3. Coffman D.D. \& Adamek M. (1999) The contributions of wind band participation to quality of life of senior adults. Music Therapy Perspectives, 17 (1), 27-31.

4. Coffman D.D. (1996). Musical backgrounds and interests of active older adult band members. Dialogue in Instrumental Music Education, 20(1), 25-34.

5. Coffman D.D. (2007)"An exploration of personality traits in older adult amateur musicians". Research \& Issues in Music Education, Volume 5: No 1.

6. Coffman, D.D. \& Levy, K. M. (1997), Senior adult bands: Music's new horizon, Music Educator's Journal, Vol. 84 No. 3 , pp. 17-22.
7. Costa P.T.\& McCrae R.R.(1992). NEO PR professional manual. Odessa, FL: Psychological Assessment Resources.

8. Ilyin E.P. (2009), Psihologiya tvorchestva, kreativnosti I odarennostey [Psychology of creativity and gifts] , "Piter"Press, Saint Petersburg. (in Russian).

9. Kaufmann L., Rawlings D. (2004). The role of personality and musical experience in shaping music students`intensions to become performers. Proceedings of the 8 international conference on Music Perception \& Cognition, Evanston, IL, USA.

10. Kemp A.E. (1981). The personality structure of the musician. Identifying a profile of traits for the performer. Psychology of Music, 9 (1),3-14.

11. Kemp A.E. (1996). The Musical Temperament: Psychology and Personality. Oxford University Press.

12. Kirnarskaya D.K. (2003), Psychology of musical activity. Theory and practice [Psihilogiya muzikalnoy deyatelnosti. Teoriya I praktika], Psychological institute RAN Press, Moscow.(in Russian).

13. Kirnarskaya D.K. (2004) Musical abilities - «The talents of the -XXI century», Psychological institute RAN Press, Moscow.' (in Russian). 
14. Kuntz T.L. Self-reported personal traits of adult amateur musicians

https://etd.ohiolink.edu/rws_etd/document/get/case13427241 53/inline

15. Lepeshinskij N.N. (2007), Adaptacija oprosnika «Shkala psihologicheskogo blagopoluchija» K. Riff. [The adaptation of the K.Ryff Scale of Psychological Wellbeing],Psychological Journal, №3, 24-37. (in Russian).

16. Parncutt R. \& McPherson G.E. (2002). The Science and Psychology of music performance: creative strategies for teaching and learning. Oxford University Press.
17. Rozgdenstvenskaya. N.V. (1980) Tvorcheskaja odarennost' i svojstva lichnosti. (Jeksperimental'noe issledovanie akterskoj odarennosti)[Creative gifts and personality features (Research of actors` talent)], L.Press 57 - 67. (in Russian).

18- Taylor D. M., Kruse N,B., Bethany J. N., Lee B.B. and Bowen T.N. (2011) Adult Musicians' Experiences in a Homogeneous Ensemble Setting. Contributions to Music Education. Vol. 38, No. 1, pp. 11-26.

19. Zigmond A.S., Snaith R.P. (1983) The Hospital Anxiety and Depression Scale.Acta Psychiatr.Scand. Vol.67. 361-370

\section{Личностные особенности музыкантов-профессионалов и аматоров}

И. Ф. Аршава, В. Ю. Кутепова-Бредун

Аннотация. В исследовании установлено, что личностные характеристики музыкантов-профессионалов и музыкантоваматоров статистически значимо отличаются по признакам принадлежности профессионалам более высокого уровня креативности в сочетании с высоким уровнем нейротизма, тревожности, склонности к переживанию астенических состояний. Профессионалы также характеризуются большей готовностью к риску. Не смотря на то, что упомянутые признаки не способствуют психологическому благополучию, в проведенном исследовании просматривается противоположная картина одаренные профессионалы чувствуют себя психологически благополучными. Музыкантам-аматорам, в отличии от профессионалов, присущи эмоциональная стабильность, более высокий уровень моральной нормативности в сочетании с положительным отношением к увлечению музыкой. Обосновывается гипотеза относительно связи выбора творческой деятельности как профессии с глубинной потребностью в самореализации одаренной личности, выражению средствами творческой деятельности присущей ей тревожности, грусти, возможности переживания состояний «потока». Для аматоров музыкальная деятельность, скорее всего, является способом развлечения, про что и говорят отличия в личностных характеристиках.

Ключевые слова: музыканты-профессионалы, аматоры, личностные отличия: нейротизм, уровни эмоциональной стабильности, моральной нормативности, психологическое благополучие 